\title{
THE REDUCTION OF HYPERCALCEMIA IN CASES OF POLYCYTHEMIA VERA BY PHENYLHYDRAZINE ${ }^{1}$
}

\author{
By GEORGE E. BROWN ANd GRACE M. ROTH \\ (From the Division of Medicine, Mayo Clinic, Rochester, Minn.)
}

(Received for publication May 25, 1928)

The range of variation in serum calcium is relatively narrow in health and in most diseases. The accepted normal level is from 9 to $11 \mathrm{mgm}$. for each $100 \mathrm{cc}$. of serum or plasma. Lowered values for serum calcium have been found in tetany (parathyroid), rickets, nephritis, osteomalacia and sprue; elevated values are rare. High values have been found by Wells in terminal acidosis and by Coates and Raiment in gout, averaging $19 \mathrm{mgm}$. for each $100 \mathrm{cc}$. of serum; these data, however, have been questioned by Cameron. Horowitz has reported values as high as $16.8 \mathrm{mgm}$. for each $100 \mathrm{cc}$. of serum in cases of acute gout, and values as high as $16.2 \mathrm{mgm}$. in five of fourteen cases of arthritis deformans. Hench found that the serum calcium was normal in four cases of gout and in twenty-five cases of infectious arthritis.

The calcium content of the whole blood in healthy subjects has been found by Kramer and Tisdall (16) to vary from 5.3 to $6.8 \mathrm{mgm}$. for each $100 \mathrm{cc}$. of blood. Calcium is absent, or present in small amounts, in the corpuscles of the blood.

The calcium content of the whole blood and of the serum in cases of polycythemia vera has not been carefully studied, probably because of the relative rarity of the disease. Rabinowitch (18), employing McCallum's gravimetric method (quantitative determination of calcium as calcium oxide) found lowered serum calcium in two cases of polycythemia vera.

1 Read before the American Society for Clinical Investigation, Washington, D. C., April 30, 1928. 


\section{METHOD OF STUDY}

Interest in this study was prompted by the clinical observation of what seemed to be an abnormal degree of calcification in the peripheral arteries in older persons with polycythemia vera, as compared to that occurring in normal persons of like age.

Fourteen typical cases of polycythemia vera were studied from this viewpoint. The spleen was enlarged in all. The number of erythrocytes, both absolute and relative, was greatly increased. The total blood volume, according to the dye $\operatorname{method}^{2}$ (11), was greatly increased, owing to the absolute increase in the erythrocytes. The patients were hospitalized; three were given the low ionic diet of Keith, Smith and Whelan (11), the others were given the general hospital diet. Determinations were made in each case of the calcium content of the whole blood and serum before and following treatment with phenylhydrazine. The sodium, potassium, magnesium, phosphate, and the sodium chloride contents of the whole blood and serum were made in five cases before and after treatment with phenylhydrazine.

The hemoglobin was determined by the method of Osgood and Haskins. For serum sodium the method of Kramer and Tisdall (14), as modified by Whelan, was used. For calcium and potassium (13), the methods of Tisdall and Kramer were used. Magnesium was determined by the method of Bogert and Plass, which is a combination of Kramer and Tisdall's (15) magnesium method and of Briggs' phosphorus method; sodium sulphite was added to bring out the blue color, as directed by Briggs. In the whole blood a modification $^{3}$ of the method of Kramer and Tisdall (16) was used for the direct quantitative determination of sodium, potassium, calcium and

2 The hermatocrit determinations were made by the dry oxalate method and a correction of 3 per cent in the cell volume was made for shrinkage.

3 Ten cubic centimeters of blood, accurately measured in a pipette, was laked with about $25 \mathrm{cc}$. of water in a $100 \mathrm{cc}$. volumetric flask. From 10 to $15 \mathrm{cc}$. of 20 per cent trichloracetic acid was added to complete the precipitation of the proteins. After the contents had been made up to volume with water, and filtered, $50 \mathrm{cc}$. of the filtrate was evaporated to dryness. The method of Kerr was employed in the removal of the trichloracetic acid. After the aliquot had been evaporated to dryness again, the residue was dissolved in $0.2 \mathrm{~N}$ hydrochloric acid, transferred to a $10 \mathrm{cc}$. volumetric flask and made up to volume. 
TABLE 1

Calcium determinations on the same blood with different methods

\begin{tabular}{|c|c|c|c|c|c|c|}
\hline \multirow[b]{2}{*}{ Case } & \multicolumn{3}{|c|}{ Serum } & \multicolumn{3}{|c|}{ Blood } \\
\hline & $\begin{array}{c}\text { Direct } \\
\text { precipitation }\end{array}$ & $\begin{array}{c}\text { Ashed } \\
\text { sample }\end{array}$ & $\underset{\text { tion }}{\text { Reprecipita- }}$ & $\begin{array}{l}\text { Ashed } \\
\text { sample }\end{array}$ & $\begin{array}{c}\text { Treated with } \\
\text { trichloracetic } \\
\text { acid }\end{array}$ & $\underset{\text { tion }}{\text { Reprecipita- }}$ \\
\hline & mgm. & mgm. & mgm. & msm. & mgm. & mgm. \\
\hline 1 & 8.4 & 8.4 & 8.4 & & 3.5 & 3.5 \\
\hline 2 & 9.8 & 9.8 & 9.8 & 3.2 & 3.7 & \\
\hline 3 & 12.7 & & 12.5 & 4.7 & 4.9 & 4.7 \\
\hline 4 & 12.9 & & 12.5 & 3.8 & 4.4 & \\
\hline 5 & 10.2 & & 10.6 & & 6.1 & 5.7 \\
\hline
\end{tabular}

TABLE 2

Calcium content of blood and serum in cases of polycythemia vera before treatment

\begin{tabular}{|c|c|c|c|c|c|c|c|c|c|c|c|c|c|}
\hline \multirow[b]{3}{*}{ జ̈ } & \multirow[b]{3}{*}{$\ddot{\mathscr{H}}$} & \multirow[b]{3}{*}{$\stackrel{8}{<}$} & \multirow{3}{*}{ 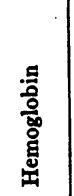 } & \multirow{3}{*}{ 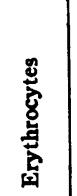 } & \multirow{3}{*}{ 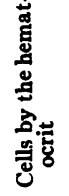 } & \multicolumn{2}{|c|}{ Blood volume } & \multicolumn{2}{|c|}{ Plasma volume } & \multicolumn{4}{|c|}{ Calcium } \\
\hline & & & & & & & & & & Whole & blood & S ru & \\
\hline & & & & & & 营 & 号 & పేँ & 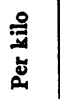 & 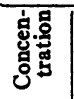 & 胥 & 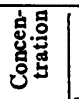 & อేँّ \\
\hline & & & $\begin{array}{c}\text { grams } \\
\text { pernt }\end{array}$ & $\begin{array}{l}\text { mil- } \\
\text { lions }\end{array}$ & $\begin{array}{l}\text { per } \\
\text { cent }\end{array}$ & cc. & $c c$. & $c c$. & $c c$. & $\begin{array}{c}\text { mgm. } \\
\text { per } \\
100 \text { cc. }\end{array}$ & mgm. & $\begin{array}{c}\underset{\text { perm. }}{\text { per }} \\
100 \mathrm{cc} .\end{array}$ & $m g m$. \\
\hline 1 & $\mathbf{M}$ & 64 & 23.0 & 5.76 & 60 & 8,580 & 136 & 3,430 & 54 & 5.2 & 445 & 12.6 & 432 \\
\hline 2 & $\mathbf{M}$ & 55 & 26.0 & 7.00 & 75 & 14,700 & 180 & 3,670 & 46 & 3.4 & 504 & 14.3 & 524 \\
\hline 3 & $\mathbf{M}$ & 50 & 25.0 & 8.18 & 76 & 14,250 & 205 & 3,420 & 49 & 4.0 & 574 & 17.3 & 591 \\
\hline 4 & $\mathbf{M}$ & 62 & 21.4 & 5.70 & 65 & 9,900 & 173 & 3,460 & 60 & & & 15.2 & 526 \\
\hline 5 & $\mathbf{M}$ & 56 & 23.4 & 7.24 & 70 & 11,110 & 173 & 3,330 & 52 & & & 15.8 & 526 \\
\hline 6 & $\mathbf{M}$ & 25 & 24.5 & 7.01 & 60 & 11,100 & 203 & 3,330 & 61 & 5.8 & 679 & 18.1 & 602 \\
\hline 7 & $\mathbf{M}$ & 39 & 27.3 & 7.60 & 76 & 17,250 & 223 & 4,140 & 53 & 3.5 & 610 & 12.9 & 534 \\
\hline 8 & $\mathbf{F}$ & 66 & 27.2 & 7.23 & 70 & 9,725 & 191 & 2,925 & 58 & 5.0 & 488 & 12.9 & 387 \\
\hline 9 & $\mathbf{M}$ & 58 & 21.3 & 8.32 & 65 & 13,550 & 191 & 4,740 & 66 & 4.9 . & 673 & 11.9 & 565 \\
\hline 10 & F & 63 & 13.6 & 5.80 & 45 & 6,560 & 135 & 3,600 & 74 & & & 12.6 & 453 \\
\hline 11 & $\mathbf{M}$ & 56 & 17.2 & 5.66 & 52 & 8,160 & 145 & 3,915 & 52 & & & 15.0 & 459 \\
\hline 12 & $\mathbf{M}$ & 59 & 18.2 & 6.62 & 65 & 9,700 & 162 & 3,400 & 58 & & & 11.1 & 377 \\
\hline 13 & $\mathbf{F}$ & 57 & 20.1 & 6.69 & 57 & 9,640 & 120 & 4,180 & 52 & & & 17.9 & 748 \\
\hline 14 & $\mathbf{M}$ & 59 & 18.2 & 6.84 & 61 & 8,020 & 140 & 3,150 & 54 & & & 12.6 & 397 \\
\hline \multicolumn{3}{|c|}{$\begin{array}{c}\text { Average } \\
\text { values. }\end{array}$} & 21.8 & 6.88 & 64 & $|10,874|$ & 169 & 3,620 & 56 & 5.0 & 567 & 14.3 & 508 \\
\hline
\end{tabular}


magnesium in small amounts of blood. Smith's method was used for chloride determinations in serum and whole blood. The serum protein was determined by the refractometric method.

TABLE 3

Polycythemia vera-studies on the calcium content of the blood and serum before and during treatment with phenylhydrazine

\begin{tabular}{|c|c|c|c|c|c|c|c|c|c|c|c|c|c|c|}
\hline \multirow[b]{3}{*}{ Uू. } & \multirow[b]{3}{*}{ \& } & \multirow{3}{*}{\multicolumn{2}{|c|}{ Date }} & \multirow{3}{*}{ 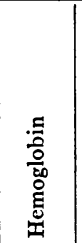 } & \multirow{3}{*}{ 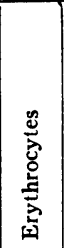 } & \multirow{3}{*}{ 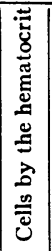 } & \multicolumn{2}{|c|}{$\begin{array}{l}\text { Blood } \\
\text { volume }\end{array}$} & \multicolumn{2}{|c|}{$\begin{array}{l}\text { Plasma } \\
\text { volume }\end{array}$} & \multicolumn{4}{|c|}{ Calcium } \\
\hline & & & & & & & \multirow[b]{2}{*}{ 焉 } & \multirow[b]{2}{*}{ 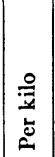 } & \multirow[b]{2}{*}{ స్త్ర } & \multirow[b]{2}{*}{ 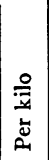 } & \multicolumn{2}{|c|}{$\begin{array}{l}\text { Whole } \\
\text { blood }\end{array}$} & \multicolumn{2}{|c|}{ Serum } \\
\hline & & & & & & & & & & & 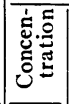 & 丞 & 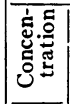 & 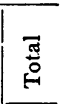 \\
\hline & & & & $\begin{array}{c}\text { grams } \\
\text { per } \\
\text { cent }\end{array}$ & $\mid \begin{array}{c}\text { mil- } \\
\text { lions }\end{array}$ & $\begin{array}{l}\text { per } \\
\text { cent }\end{array}$ & $c c$. & $c c$ & $c c$. & $c c$ & $\begin{array}{c}\text { mgm. } \\
\text { per } \\
100 \\
c c .\end{array}$ & mgm. & $\begin{array}{c}\text { mgm. } \\
\text { per } \\
100 \\
c c .\end{array}$ & $\mathrm{mgm}$. \\
\hline \multirow[t]{2}{*}{164} & \multirow[t]{2}{*}{$\mathbf{M}$} & November & 14,1925 & 23.0 & 5.76 & 60 & 8,580 & 136 & 3,430 & 54 & 5.2 & 445 & 12.6 & 432 \\
\hline & & December & 7,1925 & 12.8 & 2.99 & 35 & 4,730 & 75 & 3,070 & 48 & 7.4 & 350 & 13.1 & 402 \\
\hline \multirow[t]{2}{*}{255} & \multirow[t]{2}{*}{$\mathbf{M}$} & December & 5,1926 & 26.0 & 7.00 & 75 & 14,700 & 180 & 3,670 & 46 & 3.4 & 504 & 14.3 & 524 \\
\hline & & January & 4,1926 & 12.2 & 2.82 & 24 & 5,650 & 75 & 4,290 & 57 & 7.5 & 424 & 10.1 & 433 \\
\hline \multirow[t]{2}{*}{350} & \multirow[t]{2}{*}{$\mathbf{M}$} & January & 11,1926 & 25.0 & 8.18 & 76 & 14,250 & 205 & 3,420 & 49 & 4.0 & 574 & 17.3 & 591 \\
\hline & & February & 4,1926 & 15.2 & 4.51 & 38 & 6,450 & 104 & 4,000 & 64 & 10.0 & 645 & 12.6 & 504 \\
\hline \multirow[t]{2}{*}{$\begin{array}{ll}4 & 62\end{array}$} & \multirow[t]{2}{*}{$\mathbf{M}$} & January & 28,1925 & 21.4 & 5.70 & 65 & 9,900 & 173 & 3,460 & 60 & & & 15.2 & 526 \\
\hline & & February & 12,1925 & 12.2 & 4.62 & 40 & 6,510 & 116 & 3,910 & 70 & & & 9.3 & 364 \\
\hline \multirow[t]{3}{*}{$5 \mid 56$} & \multirow[t]{3}{*}{$\mathbf{M}$} & April & 28,1925 & 23.4 & 7.24 & 70 & 11,110 & 173 & 3,330 & 52 & & & 15.8 & 526 \\
\hline & & May & 6,1925 & 20.8 & 4.97 & 60 & 8,760 & 136 & 3,500 & 55 & & & 11.9 & 416 \\
\hline & & May & 15,1925 & 12.5 & 3.28 & 37 & 5,055 & 81 & 3,185 & 51 & & & 10.6 & 336 \\
\hline \multirow[t]{2}{*}{625} & \multirow[t]{2}{*}{$\mathbf{M}$} & January & 2,1928 & 24.5 & 7.01 & 60 & 11,100 & 203 & 3,330 & 61 & 5.8 & 679 & 18.1 & 602 \\
\hline & & January & 21,1928 & 18.1 & 5.68 & 53 & 7,660 & 150 & 3,600 & 76 & 5.7 & 440 & 11.5 & 415 \\
\hline \multirow[t]{2}{*}{739} & \multirow[t]{2}{*}{$\mathbf{M}$} & January & 18,1928 & 27.3 & 7.60 & 76 & 17,250 & 223 & 4,140 & 53 & 3.5 & 610 & 12.9 & 534 \\
\hline & & February & 13,1928 & 24.0 & 7.56 & 68 & 13,750 & 183 & 4,400 & 59 & 3.8 & 519 & 9.8 & 431 \\
\hline \multirow[t]{2}{*}{866} & $\mathbf{F}$ & October & 4,1927 & 27.2 & 7.23 & 70 & 9,725 & 191 & 2,925 & 58 & 5.0 & 488 & 12.9 & 387 \\
\hline & & Novembe & 10,1927 & 15.3 & 4.24 & 47 & 5,565 & 114 & 2,950 & 60 & 6.1 & 340 & 11.4 & 336 \\
\hline
\end{tabular}

All determinations were carried out in duplicate on fasting blood, and in several cases the direct method was checked by the trichloracetic acid technic of Kramer and Tisdall (16). Control deter- 
minations in normal subjects by the same methods showed values within the accepted normal range; control determinations of calcium by direct precipitation in the serum checked against the "ashed method" showed close approximation (table 1). To rule out possible adsorption of calcium by protein, the sample after the first titration with potassium permanganate was treated with excess potassium permanganate to oxidize all organic matter completely. The calcium in this solution was then reprecipitated with ammonium oxalate after adjustment of the hydrogen-ion concentration. The results obtained in the two precipitations were identical.

In the determinations of calcium in the whole blood, it was necessary to use the trichloracetic acid method since in the ash method the large number of erythrocytes increased the iron content to such a degree that it interfered with the permanganate titration.

\section{RESULTS}

Calcium content of serum. The calcium content of the serum previous to treatment or early in treatment is shown in table 2 . The average value for the group was $14.3 \mathrm{mgm}$. for each $100 \mathrm{cc}$. of serum. The range was from 11.1 to $18.1 \mathrm{mgm}$. In twelve of the fourteen cases values were in excess of $12 \mathrm{mgm}$. In six cases the values were $15 \mathrm{mgm}$. or more.

Calcium content of the whole blood. The calcium content of the whole blood averaged $5.0 \mathrm{mgm}$. for each $100 \mathrm{cc}$; the range was from 3.4 to $5.8 \mathrm{mgm}$. (normal values). The total circulating calcium in the serum and whole blood was calculated in seven cases (table 2). The difference in the actual amount of calcium in the serum and in the whole blood represents the calcium contained in the corpuscles. In three cases calcium was not found; in four cases, the total calcium content of the corpuscles ranged from 77 to $108 \mathrm{mgm}$. or for each $100 \mathrm{cc}$. of corpuscles from 0.67 to $1.7 \mathrm{mgm}$., amounts within the probable error of the method.

Changes in the calcium levels following treatment with phenylhydrazine (table 3). The percentage calcium content of the serum decreased in seven of eight cases following destruction of erythrocytes by phenylhydrazine, but the values after treatment did not fall below the accepted normal level. In all but one case the calcium values 


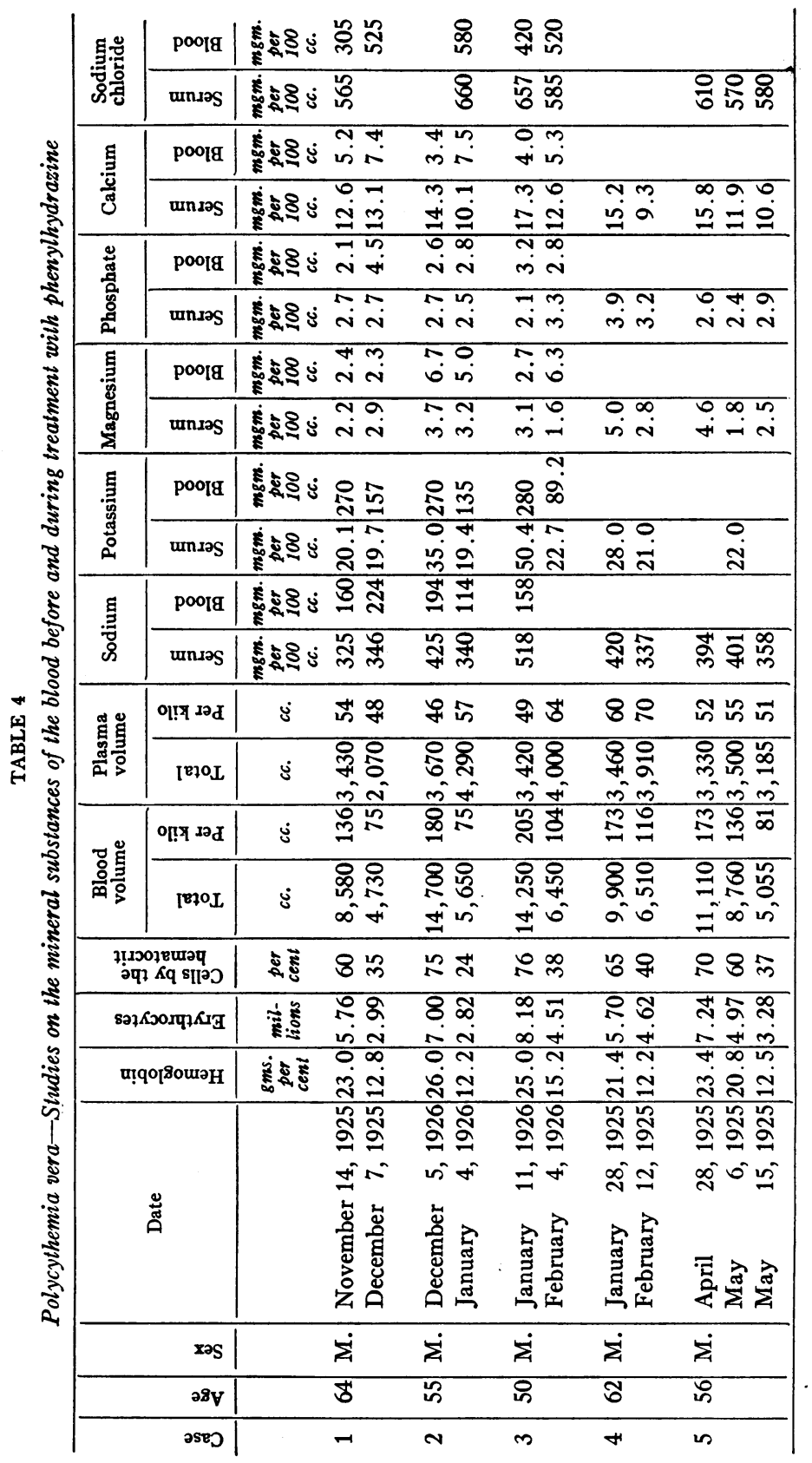


remained slightly higher than the upper limit of normal. The greatest decrease occurred in Case 6, from 18.1 to $11.5 \mathrm{mgm}$. for each $100 \mathrm{cc}$. of blood, or a decrease of $187 \mathrm{mgm}$. in the total serum calcium. The total circulating calcium in the serum decreased in every instance but not as much in proportion as the percentage values.

The percentage calcium content in the whole blood increased in four of six cases following treatment with phenylhydrazine; there was a slight decrease in the total circulating calcium of the whole blood in all but one case. There were no significant changes in the total calcium content of the corpuscles following treatment.

A close correlation could not be demonstrated in the degree of change in the content of the serum calcium and that occurring in the blood volume.

Other inorganic constituents (table 4). Sodium, potassium, magnesium, phosphate and chloride values of the serum and whole blood were determined in five cases, before and after treatment. Abnormally high values were obtained for the percentage content of serum potassium in cases 2 and 3, which returned to normal after treatment.4 In case 4 there was a moderate increase in the serum potassium; in case 5 a normal value for the serum potassium was found but the determination was made after considerable destruction of cells had occurred. The potassium in the whole blood was studied in three cases, all of which showed increased concentration; following treatment normal or subnormal values were found. The concentration of sodium, magnesium, phosphate and sodium chloride in the whole blood and serum were normal.

\section{DISCUSSION}

The basis of the hypercalcemia in polycythemia vera is not known. In the light of our recent knowledge of the rôle of the parathyroids in the regulation of the calcium in the blood, one would be tempted to theorize on functional overactivity of these glands in polycythemia vera. There is no evidence that hyperfunction ever occurs; the premise, therefore, is probably false. A second conception would be

4 Hemolysis in the serum was not ruled out by spectroscopic examination. That hemolysis produced the elevated values for potassium is unlikely, since lower values were found after treatment. 
the assumption that the increased calcium is related to an increase in he serum protein with variation in the colloid-calcium combination. In two cases studied, slight increases in the serum proteins were found. Studies have not been carried out in our cases to determine whether the diffusible or the nondiffusible fractions, or both, are increased. Methods for the study of this question are being developed.

The most logical explanation for the hypercalcemia in this disease is that it is related in some manner to the great increase in the absolute number of erythrocytes, since a definite decrease in the calcium levels in the serum follow the reduction in the number of erythrocytes. Apparently a relative increase in the ratio of corpuscles to plasma is not accompanied by an increase in the calcium, since normal values were obtained in a case of relative polycythemia vera due to dehydration, in which there were 60 per cent of cells by the hematocrit. The absence of an increase in the serum calcium in relative polycythemia vera is in accord with the work of Van Slyke. He showed that change does not occur in the inorganic ratios with variations in the relative amount of cells or plasma, since the concentration of the inorganic substances remains the same.

It could be assumed that the increased concentration of calcium represents an effort to maintain the normal inorganic ratios in the blood. Against this premise is the presence of increased values for serum calcium associated with normal values for serum potassium. There is no explanation for the increase in serum potassium in the cases in which it is observed, since it has been shown that this electrolyte does not pass through the cell membrane.

The decrease in the percentage concentration of calcium following treatment is due to a decrease in the total calcium of the serum and to dilution from the increased amount of plasma. As an example (case 2 , table 3 ), the total serum calcium decreased 17 per cent, the actual plasma volume increased 17 per cent, and the concentration of serum calcium decreased from 17.3 to $12.6 \mathrm{mgm}$. (30 per cent). Approximately half of the percentage change in calcium was related to the variation in the plasma. Either the concentration of calcium in the tissue fluid was low or an abnormal excretion of calcium occurred during hemolysis. Data regarding the excretion of calcium during the period of blood destruction are lacking. 
There are two clinical features in polycythemia vera that may be directly related to the hypercalcemia: the apparent increase in the tendency to calcification in the peripheral vessels, and, besides the high viscosity and slowing of the flow of blood, susceptibility to thrombosis. Routine roentgen-ray examination of the arteries of the extremities in this disease gives the impression that calcification of the vessels is present in a greater degree than that occurring in normal subjects of comparable ages. Hueper's investigation on the metastatic calcification in the organs of the dog following injection of parathyroid hormone is suggestive in this connection. He stated that serum calcium may be maintained at levels varying from 10 to $15 \mathrm{mgm}$. for a long time without metastatic calcification, but values in excess of this are dangerous. Since the introduction of the parathyroid hormone, its therapeutic use in a large number of cases has been reported; untoward effects of the increase in serum calcium from its use for comparatively short periods have not been reported. The work of Hunter and Aub (9) on this agent in the treatment of lead intoxication has further confirmed the high degree of tolerance exhibited by human subjects to increases in the serum calcium for periods of from three days to three weeks. Changes in the physical properties of the blood were noticeably absent.

Collip (5) defined a syndrome which he ascribed to hypercalcemia occurring in dogs following the injection of a parathyroid hormone. Marked asthenia, vomiting, diarrhea, coma, dehydration, pneumonia and hemorrhages comprise the symptoms of this intoxication; death may follow. Polycythemia vera was not observed. Collip definitely stated that with enormous doses of this hormone, hypercalcemia can be induced in normal rabbits without ill effects. He concluded that hypercalcemia alone is not deleterious in this animal but the urgent symptoms are related to the increase of phosphorus and to terminal acidosis. Apparently the tolerance of the different species of mammals to hypercalcemia varies widely, at least as far as the acute effects are concerned. The long-continued elevation of the serum calcium as obtained in polycythemia vera, perhaps a useful or compensatory adaptation, may in itself induce certain pathologic disturbances, and be productive of harm to the organism. 


\section{SUMMARY AND CONCLUSIONS}

Fourteen subjects presenting the classic picture of polycythemia vera showed an increase in the serum calcium above the accepted range of normal. The values in this substance ranged from 11.1 to 18.1 $\mathrm{mgm}$. for each $100 \mathrm{cc}$. of serum. The average value was $14.3 \mathrm{mgm}$.

Following treatment with phenylhydrazine and destruction of corpuscles to approximately normal or even subnormal values, the percentage concentration of serum calcium decreased to levels slightly above normal.

The basis of the hypercalcemia is not known. It may represent a compensatory effort to maintain the inorganic ratios of the blood. Hypercalcemia in the human subject can be tolerated without grave disturbance to the organism. The susceptibility of patients with polycythemia vera to thrombosis and to high grades of calcification in the peripheral vessels in some cases of polycythemia vera may be late results of hypercalcemia. ${ }^{5}$

\section{BIBLIOGRAPHY}

1. Bogert, L. J., and Plass, E. D., Jour. Biol. Chem., 1923, lvi, 297. The Calcium and Magnesium Content of Fetal and Maternal Blood Serum.

2. Briggs, A. P., Jour. Biol. Chem., 1922, liii, 13. A Modification of the BellDoisy Phosphate Method.

3. Cameron, A. T., Can. Med. Assn. Jour., 1926, xvi, 759. The Practical Application of Our Present Knowledge of Calcium Metabolism.

4. Coates, Vincent, and Raiment, P. C., Biochem. Jour., 1924, xviii, 921. The Calcium Content of the Blood Serum in Cases of Gout.

5. Collip, J. B., Medicine, 1926, v, 1. The Parathyroid Glands.

6. Hench, P. S., and Rentschler, E. B., Personal communication.

7. Horowitz, Philip, Am. Jour. Med. Sc., 1926, clxxi, 560. The Calcium Content of the Blood in Gout and Arthritis; Preliminary Report.

8. Hueper, Wilhelm, Arch. Path. and Lab. Med., 1927, iii, 14. Metastatic Calcifications in the Organs of the Dog after Injections of Parathyroid Extract.

${ }^{5}$ We have encountered three cases of mild polycythemia vera during the last three months with volumes of blood, 128, 131 and $140 \mathrm{cc}$. for each kilogram, with serum calcium values of $10.6,10.4$ and $11.3 \mathrm{mgm}$. respectively. These data indicate that there are cases of mild degrees of polycythemia vera in which hypercalcemia is probably not present at this stage. 
9. Hunter, Donald and Aub, J. C., Quart. Jour. Med., 1927, xx, 123. Lead Studies. XV. The Effect of the Parathyroid Hormone on the Excretion of Lead and of Calcium in Patients Suffering from Lead Poisoning.

10. Keith, N. M., Rowntree, L. G., and Geraghty, J. T.. Arch. Int. Med., 1915, xvi, 547. A Method for the Determination of Plasma and Blood Volume.

11. Keith, N. M., Smith, Florence H., and Whelan, Mary, Arch. Int. Med., 1926, xxxvii, 550. The Therapeutic Use of Diets Low in Water and in Mineral Content.

12. Kerr, S. E., Jour. Biol. Chem., 1926, lxvii, 689. Studies on the Inorganic Composition of Blood. I. The Effect of Hemorrhage on the Inorganic Composition of Serum and Corpuscles.

13. Kramer, Benjamin, and Tisdall, F. F., Jour. Biol. Chem., 1921, xlvi, 339. A Clinical Method for the Quantitative Determination of Potassium in Small Amounts of serum.

14. Kramer, Benjamin, and Tisdall, F. F., Jour. Biol. Chem., 1921, xlvi, 467. A Simple Method for the Direct Quantitative Determination of Sodium in Small Amounts of Serum.

15. Kramer, Benjamin, and Tisdall, F. F., Jour. Biol. Chem., 1921, xlvii, $475 . \quad$ A Simple Technique for the Determination of Calcium and Magnesium in Small Amounts of Serum.

16. Kramer, Benjamin, and Tisdall, F. F., Jour. Biol. Chem., 1921, xlviii, 223. The Direct Quantitative Determination of Sodium, Potassium, Calcium, and Magnesium in Small Amounts of Blood.

17. Osgood, E. E., and Haskins, H. D., Jour. Biol. Chem., 1923, lvii, 107. A New Permanent Standard for Estimation of Hemoglobin by the Acid Hematin Method.

18. Rabinowitch, I. M., Jour. Biol. Chem., 1924-1925, lxii, 667. On the Relative Proportions of Sodium, Potassium, Calcium and Magnesium in Blood Plasma in Renal Disease.

19. Smith, Millard, Jour. Biol. Chem., 1920-1921, xlv, 437. The Determination of Chlorides in Trichloracetic Acid Filtrates from Whole Blood and Plasma.

20. Van Slyke, D.D., Factors Affecting the Distribution of Electrolytes, Water and Gases in the Animal Body. Philadelphia, J. B. Lippincott, 1926, 62 pp.

21. Wells, H. G., Chemical Pathology. Philadelphia, W. B. Saunders and Co., 1925, 5th ed., 790 pp.

22. Whelan, Mary, Jour. Biol. Chem., 1925, lxiii, 585. The Effect of Intravenous Injection of Inorganic Chlorides on the Composition of Blood and Urine. 